OPERATED BY MARTIN MARIETTA ENERGY SYSTEMS. INC POST OFFICE BOX 2008, OAK RIDGE, TENNESSEE 37831.6285

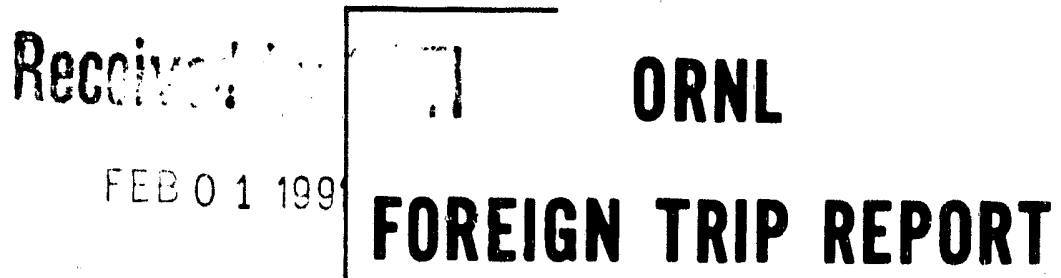

DATE:

January 15, 1991

ORNL/FTR-3858

SUBJECT:

Report of Foreign Travel to India by R. P. Krishnan, Development Staff Member, Engineering Technology Division

TO:

FROM:
A. W. Trivelpiece

R. P. Krishnan

\title{
PURPOSE:
}

At the request of the Pittsburgh Energy Technology Center (PETC), U.S. Department of Energy (USDOE), the traveler provided on-site technical assistance to the Bharat Heavy Electricals Ltd. (BHEL), Trichy, India, in the implementation of the United States Agency for International Development (USAID)/Government of India (GOI) collaborative coal projects at BHEL, Trichy. The traveler participated in the project review meetings with USAID, and the Department of Non-Conventional Energy Sources (DNES), New Delhi, along with BHEL and PETC. A site-visit to the Central Power Research Institute (CPRI), Bangalore, India, was made to assist CPRI with the formal proposal to USAID for technical assistance and training support in the coal projects envisioned for the Thermal Power Research Center (TPRC) at Nagpur, India. In addition, the traveler had discussions with the Industrial Credit and Investment Corporation of India (ICICI) on a proposed combined-cycle pressurized fluidized bed gasification pilot plant at BHEL Trichy under the USAID Program for Acceleration of Commercial Enterprise (PACER).

\section{SITES VISITED:}

12/3-10/90 Bharat Heavy Electricals Ltd., Trichy, India

12/17-19/90 U.S. Agency for International Development, New Delhi, India

Bharat Heavy Electricals Ltd., New Delhi, India
A. Srinivasulu
A. V. Narayanan
V. Gopalakrishnan
R. W. Beckman
N. V. Seshadri
W. Bollinger
K. Ramakrishnan 
SITES VISITED cont'd:

\begin{tabular}{|c|c|c|}
\hline \multirow[t]{3}{*}{$12 / 3-10 / 90$} & $\begin{array}{l}\text { Department of Non Conventional } \\
\text { Energy Sources (DNES), } \\
\text { New Delhi, India }\end{array}$ & $\begin{array}{l}\text { J. Gururaja } \\
\text { J. Meena }\end{array}$ \\
\hline & $\begin{array}{l}\text { National Thermal Power } \\
\text { Corporation (NTPC), } \\
\text { New Delhi, India }\end{array}$ & N. K. Balasubramanian \\
\hline & $\begin{array}{l}\text { Industrial Credit and Investment } \\
\text { Corporation of India, PACER } \\
\text { Secretariat, Bombay, India }\end{array}$ & P. H. Vaidya \\
\hline $12 / 21-22 / 90$ & $\begin{array}{l}\text { Central Power Research Institute } \\
\text { (CPRI), Bangalore, India }\end{array}$ & $\begin{array}{l}\text { M. Ramamoorty } \\
\text { P. R. Krishnamurthy }\end{array}$ \\
\hline $12 / 24-28 / 90$ & $\begin{array}{l}\text { Bharat Heavy Electricals Ltd., } \\
\text { Trichy, India }\end{array}$ & $\begin{array}{l}\text { A. V. Narayanan } \\
\text { V. Gopalakrishnan } \\
\text { K. Ramachandra } \\
\text { K. Chandrasekhar } \\
\text { S. Gowrishankar } \\
\text { S. Arunachalam } \\
\text { S. K Nandakumar }\end{array}$ \\
\hline
\end{tabular}

\begin{abstract}
:
Under the Phase II, Alternative Energy Resources Development (AERD) project of the United States Agency for International Development (USAID) and the Government of India (GOI), five coliaborative coal projects have been initiated in the areas of: (1) $\mathrm{NO}_{X} / \mathrm{SO}_{X}$ control from coal-fired power plants, (2) slagging combustor development for high-ash Indian coals, (3) characterization of Indian coals for combustion and gasification, (4) diagnostic studies for prediction of power plant life expectancy, and (5) environmental and natural resource analysis of coal cycle. The Pittsburgh Energy Technology Center (PETC) has the implementation responsibility for these projects. The Indian collaborative institutions identified for these projects are the Bharat Heavy Electricals Ltd. (BHEL), Trichy, (projects 14), and the Tata Energy Research Institute (TERI) for project 5. The Oak Ridge National Laboratory (ORNL) is providing cross-cut technical coordination and support for these five projects.
\end{abstract}

The traveler and Dr. William C. Peters, the USAID Coal Program manager, PETC-USDOE participated in the project review meetings at USAID and DNES in New Delhi along with BHEL. The main purpose of these meetings was to finalize the proposed activities including the training of BHEL engineers, the 
schedule and the additional funding required from USAID and BHEL to complete the coal projects. The AERD project completion date has been extended from December 1990 to June 1992.

At Trichy, the traveler, with the BHEL project staff, initiated the structural design and civil engineering activities for the Fuels Evaluation Test Facility (FETF), planned the strategy and equipment required for the baseline environmental emissions monitoring at a coal-fired power plant in India, and prepared the agenda for the life-extension and slagging combustion projects.

At CPRI, the technical assistance needed from U.S. institutions and the areas for training of the CPRI staff for the TPRC at Nagpur were identified. The preliminary budget was also prepared. The formal proposal to USAID will be sent by the Department of Power (DOP) in late January 1991.

The trip was beneficial to all the participants in the USAID coal projects. Meetings with USAID and DNES were essential to firm up the activities, schedule and funding in each of the four coal projects. Continued technical assistance from PETC and ORNL in future USAID coal projects in India can be expected. 


\section{REPORT ON SITE ACTIVITIES AT BHEL, TRICHY}

\section{Project 1 - DEVELOPMENT OF POLLUTION CONTROL STRATEGIES FOR ABATEMENT OF $\mathrm{NO}_{\mathrm{X}}$ SO $_{\mathrm{X}}$ EMISSIONS FROM FOSSL FIRED PLANTS}

In this project, the objective is to quantify the current emission levels of $\mathrm{NO}_{\mathrm{X}}$ and $\mathrm{SO}_{\mathrm{X}}$ from operating coal-fired power plants to the extent needed to propose pollution control strategies. Baseline monitoring of one or two selected Indian utilities for $\mathrm{NO}_{X}$ and $\mathrm{SO}_{X}$ emissions with technical assistance from U.S. companies will be performed. Some of the essential equipment and accessories for $\mathrm{NO}_{X} / \mathrm{SO}_{\mathrm{X}}$ measurements are being procured in the U.S. BHEL engineers will visit U.S. utilities and other organizations to get a first-hand knowledge of the current practices for $\mathrm{NO}_{\mathbf{X}} / \mathrm{SO}_{\mathbf{X}}$ control, and the strategies being developed under the U.S. DOE Clean Coal Technology Program.

The equipment and manpower for conducting the baseline emissions monitoring in India was discussed during this visit. BHEL has carried out $N O_{X}$ measurements in $500 \mathrm{MW}$ and 200 MW units employing a portable electrochemical flue gas analyzer (LANCOM Model 3400). This instrument does not meet the U.S. Environmental Protection Agency (USEPA) specifications for $\mathrm{NO}_{X}$ measurements. $\mathrm{SO}_{X}$ measurements have not been made in the 500 MW and $200 \mathrm{MW}$ units. Oxygen, carbon monoxide, carbon dioxide and particulates have been measured, but the accuracy of the measurements is questionable. BHEL will be contacting other Indian agencies (the National Thermal Power Corporation and the Pollution Control Center) to ascertain whether a portable, complete flue gas analysis system is available for the baseline monitoring. The alternative will be to have the U.S. technical experts participating in the baseline monitoring carry the critical equipment with them to India.

Initially, the emissions monitoring will be conducted in a $200 \mathrm{MW}$ tangential fired unit. A baseline test series for a minimum of one week at high, medium and low steam loads will be attempted. The tests will be repeated under low-NO $\mathrm{X}$ producing operating conditions to determine the parameters having the most pronounced effect on $\mathrm{NO}_{\mathrm{X}}$.

The monitoring will typically include:

- Continuous emissions monitoring (CEM) system for online $\mathrm{NO}_{\mathrm{X}}, \mathrm{CO}, \mathrm{CO}_{2}, \mathrm{SO}_{2}$ and $\mathrm{O}_{2}$ utilizing a multi-probe sampling grid for adequate coverage of duct cross-section with U.S. EPA approved monitors and gas conditioning system.

- Selected monitoring of total hydrocarbons (THC) using gas grab methods approved by the U.S. EPA.

- Selected measurements of Loss on Ignition (LOI) and unburnt carbon in the ash for thermal efficiency loss calculations using grab particulate samples in the duct upstream of the ESP. Collection of these sample will be based on U.S. EPA approved methods.

- Grab samples coal test composites for laboratory proximate/ultimate analyses using standard ASTM sample collection and coal analyses methods. 
The data from the $200 \mathrm{MW}$ will be analyzed to establish the pollutant levels under normal power plant operating conditions. A second series of tests in the $500 \mathrm{MW}$ unit will be conducted by BHEL and the Indian utility at a later date in consultation with the U.S. technical experts. Provision for concentric tangential firing and overfire air injection for $\mathrm{NO}_{\mathrm{X}}$ reduction are available in the larger unit. These control options will be tested after the visit of the BHEL engineers to U.S. utilities and other installations where in-situ methods for $\mathrm{NO}_{\mathrm{X}}$ reduction are under investigation.

\section{Project 2 - DEVELOPMENT OF SLAGGING COMBUSTOR FOR ADVANCED POWER GENERATION APPLICATIONS}

BHEL has designed and erected a $3.0 \mathrm{MW}(\mathrm{t})$ coal-fired slagging combustor at Trichy. The combustor has undergone several modifications based on preliminary trial runs with Indian coals. Only a few trials have resulted in slag formation on the combustor walls. The design and operating parameters for slag formation are yet to be established. Through this collaborative project, the design and operating conditions will be confirmed and appropriate modifications to the existing combustor will be recommended. Technical assistance and diagnostic hardware are being provided by USAID for this project.

The slagging coal combustor was commissioned in March 1989 and preliminary tests were conducted with a bituminous coal, a coal washery middling and Neyveli lignite. These tests did result in some slag formation on the combustor wall but the quantity of slag produced and the thickness of the slag deposit were way below the design expectations. Tests have also been conducted with a fluxing agent to improve the slag fusion and slag flow properties. Some improvements were observed, particularly with lignite, but there is still a lot more developmental work required to optimize the design and operating conditions.

The agenda for future activities include modifications in both hardware and operating conditions to achieve continuous and uniform slag deposition and minimum slag carryover in the flue gas. Diagnostic tools will be incorporated in the combustor to monitor the slag formation, slag layer thickness and heat flux in the vicinity of the combustor walls. A U.S. technical expert will visit BHEL, Trichy in March-April 1991 to carry out a design review of the existing combustor and to suggest the modifications needed to improve the combustor performance. Later, BHEL engineers will visit the U.S. for interaction and technical discussions with experts at PETC, Morgantown Energy Technology Center (METC), Brigham Young University, Sandia National Laboratory, Argonne National Laboratory, and the University of Tennessee Space Institute. Testing on lignites will resume after the modifications are made to the existing combustor.

\section{Project 3 - ADVANCED DIAGNOSTIC STUDIES FOR PREDICTION OF LIFE EXPECTANCY OF EXISTING POWER PLANTS}

Under this AERD project, technical assistance is being provided to BHEL in the areas of diagnostic techniques for prediction of remaining life and life extension of coal-fired power plants. 
The major accomplishments to date have been the visits of two EPRI technical experts and an EPRI consultant to BHEL, Indian utilities and power agencies. Through these visits, the current practices and methodologies used for prediction of remaining life of power plant components in the U.S. were communicated to the Indian engineers. Two seminars and two workshops were conducted in India with the participation of the Indian utilities, boiler vendors and power research agencies to disseminate the information. Equipment for this project has been finalized and procurement is underway.

Two BHEL engineers will be in the U.S. in May-June 1991 for four weeks. The purpose of the visit is to participate in an actual life assessment project at a U.S. utility to get acquainted with the state-of-the-art techniques employed for in-situ oxide scale thickness measurement in boiler tubes, creep and fatigue analysis of thick walled components, residual creep assessment, boiler and header life assessment and nondestructive techniques for creep and crack estimation. ORNL will coordinate the site visits and meetings with the U.S. institutions. Interpretation of the field data and predicting residual life from the field measurements will be stressed during the visit of the BHEL engineers. They will also attend the third conference on cycle chemistry and boiler tube failures organized by EPRI in the first week of June 1991.

A team of U.S. experts will participate in a life extension demonstration with BHEL at an Indian utility which is tentatively planned in August 1991.

\section{Project 4 - BHEL FUEL EVALUATION TEST FACILTTY}

The impact of coal quality on boiler output and operation is quite significant and cannot be judged by laboratory data on coal composition and ash properties. Pilot-scale combustion tests are mandatory to provide boiler performance data on combustion efficiency, fuel ignition characteristics, flame stabilization, slagging, fouling, erosion and corrosion of boiler components, and gaseous and particulate emissions: Pilot-scale tests are also necessary for the selection of the appropriate coal and/or coal mixtures for full-scale burning in commercial boilers. In India there is no facility available to conduct screening tests on coal. The USAID/BHEL facility will be the first, state-of-the-art, pilot-scale, fuel evaluation test facility (FETF) in the country. A 3.0 million Btu/h FETF will be erected at Trichy. The primary features of the facility include:

- Simulation of a commercial utility boiler with bottom ash pit, firebox, radiant section, nose section, convection pass and exhaust section.

- Variable firing modes; tangential, front and opposed wall.

- Multifuel (coal and oil) and cofiring capabilities.

- Simultaneous feed of different fuels.

- Removable sections in the radiant zone to vary combustor volume and residence time.

- Variable volumetric heat release operation.

- Operation at a wide range of fuel-to-air ratios.

- Adjustable air preheat temperatures $\left(70^{\circ}\right.$ to $\left.750^{\circ} \mathrm{F}\right)$.

- Flue gas recirculation through the burners and furnace hopper for $\mathrm{NO}_{X}$ control.

- Fouling probes in the convection zone. 
- Erosion monitoring in the convection tube surfaces.

- Corrosion monitoring of the radiant and convection tube surfaces.

- Continuous flue gas monitoring $\left(\mathrm{O}_{2}, \mathrm{CO}_{2}, \mathrm{CO}, \mathrm{SO}_{2}, \mathrm{NO}_{\mathrm{X}}\right)$.

- Particulate collection and analysis at selected locations in the combustor, including baghouse.

- Monitoring of critical parameters to perform complete mass and energy balances.

In addition, the facility will be equipped with:

- A computer-based data acquisition and control system.

- Photographic and video recording of flame patterns and ash deposition.

- Advanced diagnostic instrumentation and analytical support.

The design of the combustor and auxiliary systems, the specifications of equipment for the FETF, and the general layout of the test facility have been completed. Process instrumentation and data acquisition system for the FETF are yet to be specified. This will be taken up after the location and frequency of sampling of the process and control parameters are finalized.

A design review was completed at PETC in December 1990. Attendees included engineers from BHEL, Acurex, Gilbert-Commonwealth and the PETC coal combustion division staff. Two BHEL engineers were deputed for eight weeks in November-December 1990 to participate in the design review and in the combustion tests on two Indian coals in the PETC fuels evaluation test facility. The combustion tests were intended to provide baseline data on flame stability, carbon burnout, emissions, and ash deposition. Characterization of the coal and ash samples and analysis of the test data are in progress. The information gathered in these tests was used to validate some of the critical design parameters selected for the FETF. In addition, the tests provided training and exposure to the BHEL engineers on start-up, shut-down, operation of the FETF, and the safety procedures for fireside performance testing.

The traveler had detailed discussions with the BHEL engineers in Trichy on December 27-28, 1990 , after their return. All the necessary inputs for calculating the loads and for preparing the final engineering drawings for the foundation, supports, platforms, columns, and the building were prepared. BHEL is proceeding with the civil engineering activities, and the foundation/structural drawings will be released in February-March 1991. Site activities will commence in April 1991. Fabrication drawings for the combustor and auxiliary components have also been taken up in parallel. The commercial boiler design group at BHEL was consulted during this visit to ensure that the FETF design and the type of measurements envisioned in the FETF will be useful for the commercial boilers. The design group preferred using steam for the heat transfer fluid in the slag panels and waterwalls rather than Dowtherm or ethylene glycol. Steam has the advantage because it is also the heat transfer medium in boilers. In addition, it is nontoxic unlike Dowtherm or ethylene glycol. A decision is pending on this issue at present because there is no steam source available in the vicinity of the proposed FETF site. Concurrence of the BHEL management will be required to provide a dedicated steam supply source for the FETF and would entail a substantial 
investment from BHEL. Measurements of in-situ ash emissivity, waterwall heat pick-up and thermal properties of the refractory and insulating material during furnace operation were suggested as being extremely relevant and useful for the design of commercial boilers. 


\section{AERD PROJECT REVIEW MEETING AT DNES, NEW DEILHI}

The meeting was convened in DNES on December 17,1990, to discuss and review the various projects taken up for joint implementation by the Indian and U.S. collaborating institutions under the AERD projects. Attendees at the meeting included:

Dr. J. Gururaja, Advisor, DNES, Government of India

Mr. J. R. Meena, Principal Scientific Officer, DNES

Mr. Robert Beckman, Director, Technology Development and Enterprise (TDE), USAID, New Delhi

Mr. N. V. Seshadri, Energy Specialist, USAID, New Delhi

Mr. V. Gopalakrishnan, Deputy General Manager, R\&D, BHEL, Trichy

1)r. William C. Peters, USAID Coal Program Manager, PETC/USDOE

Dr. R. P. Krishnan, USAID Coal Projects Technical Coordinator, ORNL

Mr. Beckman stated that the completion date for the coal-biomass projects has been extended to June 30,1992, and the next step was to identify the remaining activities and the additional funds for completing the activities. Dr. Peters and Dr. Krishnan apprised the members of the accomplishments to date on the various coal conversion projects. They indicated that the design of the Fueis Evaluation Test Facility (FETF) to be erected at BHEL, Trichy was completed, and a review of the design was also accomplished with BHEL engineers and Acurex at PETC. In addition, 15 tons of Neyveli lignite and 12 tons of Kathara middlings which were shipped by BHEL to PETC were being tested in the PETC fuels test evaluation facility. Two BHEL engineers were deputed for eight weeks to participate in the testing and the design review discussions. Equipment specification for all the coal projects has been completed and procurement is underway. Shipment will be initiated in March-Apri'. 1991. BHEL is taking appropriate action to get the customs duty exemption for the equipment from GOI. The remaining activities to be completed in the coal projects are scheduled for FY 1991. Simultaneously, BHEL is taking appiopriate action to get the consignment cleared through customs in India.

(1) Erection and commissioning of the FETF at BHEL, Trichy, followed by shakedown oi the test facility and testing of Indian fuels jointly by U.S. experts and BHEL engineers;

(2) Baseline monitoring of $\mathrm{NO}_{X} / \mathrm{SO}_{X}$ emissions from existing fossil-fired power plants with U.S. technical experts;

(3) Demonstration of state-of-the-art diagnostic techniques for power plant component life assessment and prediction with technical experts from Electric Power Research Institute ar/ U.S. consultants along with BHEL, Trichy at Indian utilities;

(4) Design modifications of the existing 3.0 MW slagging combustor at BHEL, Trichy with U.S. experts and testing of Indian coals in the slagging combustor;

(5) Training of eight BHEL engineers in U.S. institutions under the four coal projects. 
Mr. Meena summarized the accomplishments in the biomass project at DNES and Sandia National Laboratory (SNL), Albuquerque. Equipment specifications for the National Solar Photovoltaic Test Facility (NSPTF), and the procurement and shipment schedule for the equipment were completed jointly by DNES and SNL during the visit of Dr. B. Bhargava, DNES to SNL in October 1990. Remaining activities in the project are the erection and commissioning of the NSPTF which will be completed by June 1991. Training of four Indian scientists in the U.S. for a duration of eight weeks each will be completed by December 1991.

Mr. Seshadri discussed the budget issues. Out of the total allocation of $\$ 7$ million for the AERD, $\$ 5.68$ million has been disbursed. The balance of $\$ 1.32$ million has been committed, mainly towards purchase of equipment. Dr. Peters stated that there will be no funds available to support the technical services of U.S. institutions participating in the coal projects and training of Indian engineers after December 1990. It was agreed that additional funds will have to be made available immediately to continue the activitie: in the coal projects.

Dr. Gururaja expressed appreciation to USAID for the timely and continued support. He mentioned that under the existing U.S.-India Science and Technology Agreement, the coal and biomass conversion is a high-priority area and will continue to receive the support from GOI. He also stressed the need to look for opportunities for collaborative efforts in energy conservation, energy efficiency and aiternative fuels development. 


\subsection{MEETING WTTH NATIONAL THERMAL POWER CORPORATION (NTPC)}

On December 19, 1990, the traveler met Mr. N. K. Balasubramaniam, Director, NTPC, New Delhi, along with Mr. V. Gopalakrishnan, Deputy General Manager, BHEL, Trichy. The possibility of conducting the baseline $\mathrm{NO}_{\mathrm{X}} / \mathrm{SO}_{\mathrm{X}}$ monitoring at an NTPC power plant was discussed. Mr. Balasubramaniam indicated that one of the $200 \mathrm{MW}$ or $500 \mathrm{MW}$ NTPC boilers in the Singrauli or Ramagundam sites could be considered for the baseline study. He also mentioned that an Environmental Impact Assessment (EIA) has been conducted for the Singrauli region for the NTPC. As part of the EIA, ambient air quality measurements were made in the region. The equipment used in the air quality measurements is available, but it is to be confirmed whether the equipment will meet the USEPA specifications for $\mathrm{NO}_{X} / S O_{X}$ and other constituents. NTPC is interested in collaborating with BHEL in the baseline emissions monitoring and has agreed to cooperate by providing equipment and/or personnel to the extent possible.

$\mathrm{Mr}$. Balasubramaniam mentioned the urgency at NTPC to come up with a scherne for largescale utilization of flyash. At present flyash is very much underutilized in India. The annual production is around 36 million tons out of which only $2 \%$ is presently utilized. A flyash utilization wing has been dedicated at NTPC to look at both indigenous and foreign technologies available to convert flyash into useful materials. At present, the only useful product that is being made is brick and, to some extent, flyash is also used in cement and concrete production. Other options have not been thoroughly investigated. In this context, the traveler mentioned that Dr. Oscar Manz, a retired professor from the University of North Dakota and an internationally recognized expert on flyash will be visiting India in March 1991 for consultations in the USAID-India coal projects. He will be available for discussions with NTPC. Mr. Balasubramaniam indicated that the Department of Power (DOP) would extend full support for collaborative projects in flyash utilization under the USAID Technical Assistance Support Program. Potential areas for collaboration will be discussed during Dr. Manz's visit to NTPC in March 1991. 


\subsection{MEETING WTTH ICICI}

The traveler met with Dr. P. H. Vaidya, Manager, PACER Secretariat, ICICI and with Mr. K Ramakrishnan, Director, Engineering/R\&D, BHEL, New Delhi. ICICI has been encouraging the private sector and the public sector undertakings, such as BHEL, to submit proposals in coal technology development. Under the PACER Program guidelines, the USAID funds can be made available as loans, conditional grants and outright grants for commercially viable, market-driven energy-related projects. Prior concerns voiced by BHEL were with respect to the conditional grant awards which necessitate a payback of the grant if the project is successful and commercialized. During this meeting, this issue was discussed and it is now clear that BHEL will proceed with a proposal to ICICI under the PACER guidelines. Mr. Ramakrishnan indicated that the Pressurized Fluidized Bed Gasification (PFBG) based combined-cycle pilot plant contemplated at BHEL, Trichy could be a candidate for funding under the PACER program. At his request, the traveler met with Mr. A. V. Narayanan, General Manager, Engineering, and Commercial Coordination and discussed the PFBG proposal. It was agreed that this would be a sound project for implementation under PACER and accordingly a letter of intent was sent by BHEL to ICICI (See Appendix A). Assistance from the U.S. DOE, ORNL, and the U.S. engineering firms as a necessary condition to successfully implement this project was expressed by BHEL. The PFBG pilot plant will provide engineering and operating data for the larger $30.0 \mathrm{MW}$ PFBG combinedcycle demonstration plant. Coal-based combined-cycle power generation is considered to be the best near-term option for efficient and environmentally safe large-scale power generation. The Council of Scientific and Industrial Research, GOI, is spearheading a U.S.-Indian collaborative effort to eventually build a $30.0 \mathrm{MW}$ combined-cycle coal-based gasification plant. 


\subsection{STIE VISIT TO CPRI, BANGALORE}

The visit to CPRI was, in essence, a follow-up to an earlier visit in September 5-6, 1990, hy ORNL and PETC. In the last visit, detailed discussions were held with the CPRI staff on the proposed activities in the Thennal Power Research Center (TPRC) which are being set up by CPRI under a grant from the Department of Power, Government of India. Funding from GOI is approximately $\$ 10$ million (U.S. dollars), over a four-year period (1990-1994). Fullfledged research and teit facilities for combustion studies, fuel evaluation, coal beneficiation, power plant component wear and remaining life estimation, and environmental pollution assessmen and control from coal-fired utilities are planned at the TPRC to be set up at Koradi, Nagpur. Technical assistance and training of CPRI engineers in U.S. institutions is being requested by CPRI under the USAYD Technical Assistance and Support Program.

The USAID-CPRI program will be implemented over a four-year period under four project titles: (1) coal combustion, (2) coal beneficiation. (3) power plant component life assessment, and (4) environmental impact assessment of coal-fired power plants. In each projece, technical assistance, short-term (up to 3 months) and long-term (up to 6 months) training of CPRI scientists/engineers in the U.S. are envisioned. U.S. technical expertise will be provided by on-site technical assistance to the CPRI staff in setting up pilot-scale test facilities, participating in the design of the test facilities and laboratory experiments, assisting in the screening and selecting of appropriate technologies to be studied under each project, establishing the guidelines and methodologies for performing environmental impact assessment and power plant siting, and identifying the technciogies best suited for utilization of Indian flyash.

Detailed budget estimates are provided in the CPRI proposal. The funds requested from USAID over the four-year period are $\$ 3.0$ million (U.S. dollars). The CPRI investment in the projects will be approximately $\$ 2.3$ million (U.S. dollars). The proposal will be sent to the Department of Power for review and concurrence in late January 1991. USAID will receive the formal proposal from GOI. 


\section{CONCLUSIONS}

Technical assistance was provided to BHEL, Trichy, in the implementation of the coal projects. The projects are on schedule. Remaining activities in each project and the schedule for their completion were prepared jointly with BHEL. USAID and DNES have agreed to provide additional funds to carry out the remaining activities. The project completion data has now been officially extended to June 30, 1992.

The FEIF design has been reviewert extensively by experts in the U.S. Maximum flexibility has been incorporated in the FETF to test a wide range of coals and operating conditions. State-of-the-art instrumentation is being used in the FETF. When completed, the facility will provide valuable information to the U.S. and Indian boiler manufacturers and utilities. Continued participation of PETC and ORNL will be necessary to successfully commission the FETF.

risc:Lisions with ICICI, NTPC and CPRI were substantive and helped to short-list the future collaborative coal projects that can be taken up under the USAID Technical Assistance Support Program and the USAID PACER program. Undoubtedly, the environmental aspects of coal-based power generation is on the top of the list. With the massive capacity expansion planned by the power sector for the next decade, coal-based power generation plants will be mandated to install pollution control equipment as well as identify how they propose to utilize the flyash. The CPRI and NTPC collaborative projects in flyash utilization are timely and technically sound. The USAID coal projects are providing opportunities for screening and testing US technologies and equipment which are best suited for the Indian conditions. In particular, the environmental issues related to coal-based power generation are being addressed in these collaborative projects, and the information generat will help in identifying the best control options for the future commercial coal-based, utilities in India.

Lastly, the communication and valuable linkages established with the Indian technical community in these projects are helping the U.S. participants to understand and appreciate the problems related to the utilization of high-ash content coals and to help find solutions. 
APPENDIX A

LETTER OF INTENT FROM BHEL TO ICICI FOR THE PRESSURIZED FLUIDIZED BED GASIFICATION PILOT-PLANT UNDER THE USAID PACER PROGRAM 
Dear Dr, Vaidya,

This has reference to the discussions you had with Mr.K.Ramakrishnan, Director/Engineering \& R\&D, BHEL on 17 Dec. 1990 at Delhi along with Dr.R.P.Krishnn of ORNL-USA, regarding PACER PROAECTS.

From the Tinuchy unit of BHEL, we would like to propose the installation of a Pressurised Fluid Bed Gasifier based combined cycle plant under the PACER Programe.

As you are aware, combined Cycle Plants for power generation with a combination of gas turbines and ateam turbines, using natural gas or fuel oil, is a developed technology in the world. Our project is to get prcoouriacd clean fuel yat Ir uil crul and use $1 \mathrm{e}$ for the gas turbine as the fuel, instead of natural gas or fuel oil. For economic aize of gasifier, pressurised fluid bed gasification is considered to be the appropriate technology for Indian coals. We already have an installation of $4 \mathrm{MN}$ gas turbine at our plant herc, which can be fed by this pressurised fluid bed gasifier.

such integrated coal gasification combined cycle plants are in develogmental stages all over the world. It is our view that a camercial plant will be techno-economically viable in sizes of more than $30 \mathrm{MN}$. Our proposed pilot plant will be of $4 \mathrm{MW}$ aize and based on the data collected, future comercialisation to higher sizes would become feamible. This is also considered as one of the environmentally benign systen for powe: generation. Based on current estimates, the pilot plant we propose at Tiruchy will involve an expenditure of about 6 to 7 Million us Dollars equivalent.

I have also discussed this proposal with Dr. R.P. Krighnan during his visit to Tinuchy on $26 \mathrm{DeC} 1990$. Looking at the prospects of future commercialisation to bigger unito, he is also of the view that this is a feasible project for PACFR mnnidertion. 
It will be our pleasure if you can nuke a visit to tinchy in the first or eccond week of January 1991 whon we ran ghow you round the existing R\&D facilities at Tinxchy. and give further details you may

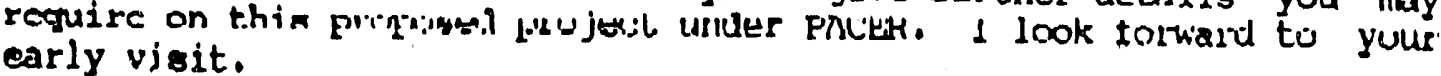

Best wighes for a Happy and Prosperous New Year.

With warm regards,

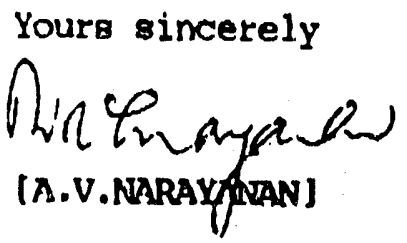

Dr. P.H. VAIDYa

Asst Ceneral Manager

Industrial Credit \& Investment

Corporation of India Ltd

163, Backliay Recilamation (Road No.3)

BOMBAY 400020

Copy to

Dr. R.P. Krishnan, ORNL-USA (CAMP: TIRUCRYY) 


\section{APPENDIX B}

\section{IIINERARY}

11/29/90-12/1/90 Travel from Oak Ridge to New Delhi, India

12/2/90 Travel to Trichy, India via Madras

12/3-10/90 BHEL, Trichy, India

$12 / 11-15 / 90 \quad$ Vacation

12/16/90 Travel from Bombay to New Deihi

12/17-19/90 New Delhi meetings with USAID, BHEL, DNES, NTPC and ICICI

12/20/90 Travel from New Delhi to Bangalore

12/21-22/90 Central Power Research Institute, Bangalore, India

12/24-28/90 BHEL, Trichy, India

12/29/90 Travel from Trichy to New Delhi

12/31/90 Travel from New Delhi to Oak Ridge 

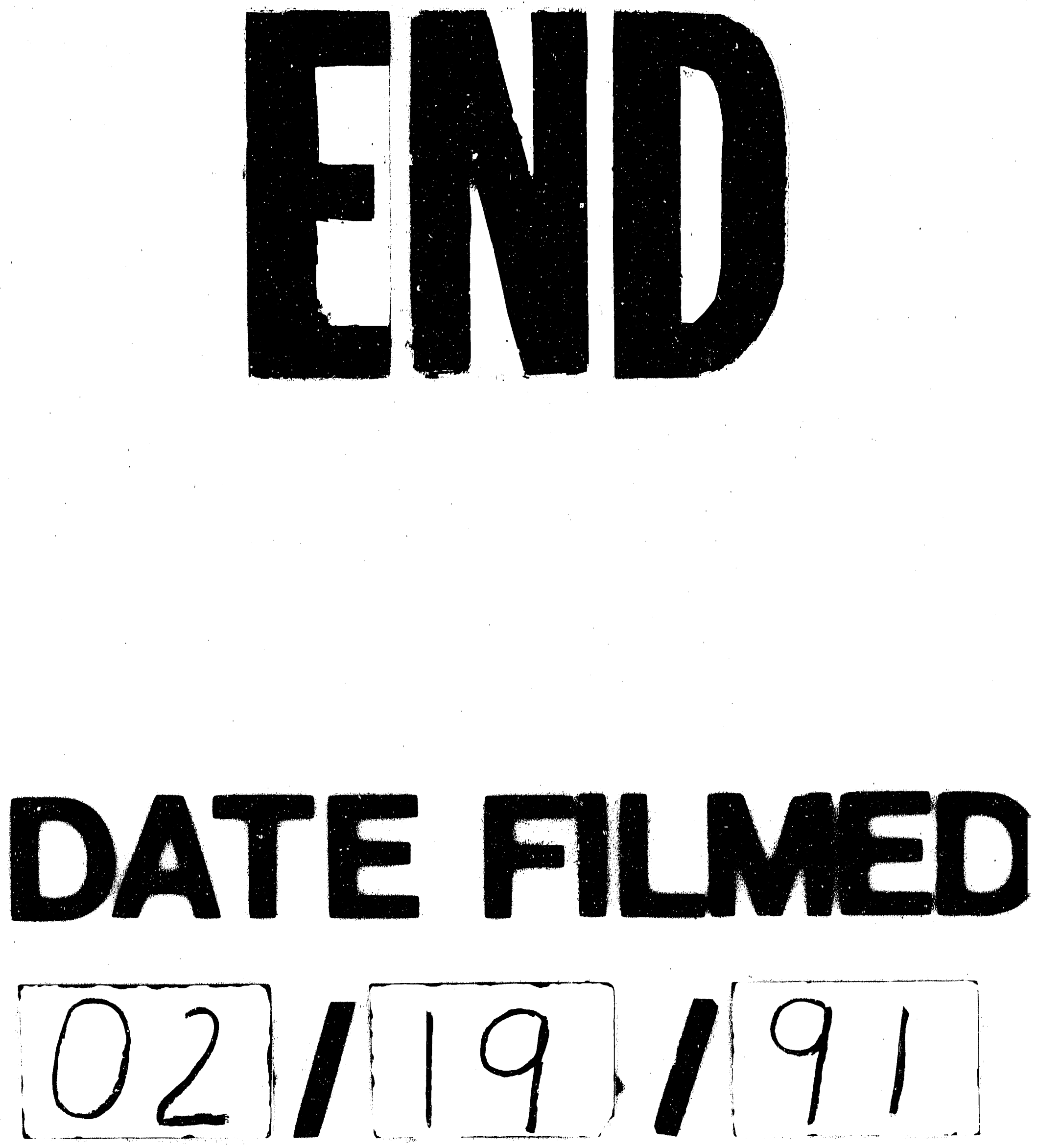
